\title{
A NEW SYSTEMATIC APPROACH FOR WAREHOUSE MANAGEMENT SYSTEM EVALUATION
}

\author{
Sinan Apak, Hakan Tozan, Ozalp Vayvay
}

Original scientific paper

Warehouse management is one of the most important legs in supply chain operations and production management. To support that warehouse execution, a warehouse management system is required. Many warehouses have used various methods to handle this difficult and time consuming evaluation process. The purpose of this paper is to provide a decision support model to make a careful evaluation of warehouse management system. Purchasing an appropriate warehouse management system in a supply value chain is not an easy decision making and is related to fuzziness and uncertainty, which should be considered as a large number of complex factors in multiple evaluation criteria. A Fuzzy Multi Criteria Decision Making approach is adopted to effectively evaluate warehouse management systems. To provide a practical guidance for other companies a real life framework is presented with an application.

Keywords: ELECTRE; Fuzzy AHP; Fuzzy ANP; Fuzzy Multi Criteria Decision Making; TOPSIS; warehouse management system

Novi sustavni pristup ocjenjivanju sustava upravljanja skladištem

Izvorni znanstveni članak

Upravljanje skladištem je jedan od najvažnijih čimbenika u operacijama lanca opskrbe i upravljanja proizvodnjom. Kao podrška vođenju skladišta, potreban je sustav upravljanja skladištem. Mnoga su skladišta koristila različite metode za provođenje tog teškog i dugotrajnog procesa evaluacije. Cilj ovoga rada je stvoriti model za podršku donesenim odlukama o ocjeni sustava upravljanja skladištem. Kupnja odgovarajućeg sustava za upravljanje skladištem u lancu opskrbe nije laka odluka i povezana je s nejasnoćama i nesigurnošću, odnosno velikim brojem složenih čimbenika u višestrukim kriterijima ocjenjivanja. Za učinkovitu ocjenu sustava upravljanja skladištem usvojen je pristup zasnovan na brojnim nejasnim kriterijima (Fuzzy Multi Criteria Decision Making). Kao praktičan vodič za druge kompanije dat je prikaz realnog stanja s primjenom.

Ključne riječi: ELECTRE; Fuzzy AHP; Fuzzy AHP; fuzzy multi kriteriji odlučivanja; sustav upravljanje skladištem; TOPSIS

\section{Introduction}

Today's businesses are continuously expanding to include warehouses and supply chain partners from all over the world and importance of warehouses is strongly increasing. Warehousing concept concerns inventory management activities that take place within the storage areas, and warehouses such as receiving of goods, purchasing, shipping of goods, order picking, collecting and sorting activities [1]. Warehouse Management (WM) is not just purchasing, storing, and shipping in the limits of a warehouse; it is much more complex and exceeds the physical boundaries of warehouses. Warehouse Management system (WMS) is used to increase the performance of the warehouse by directing efficient managerial implications and in order to develop precise inventory as a result of recording warehouse transactions $[2,3]$. WMS is still gaining functionality and can be defined merely as a system to control storage of materials and movement in the storage area. The role of WMS is expanding in managerial areas such as transportation, order, and complete financial systems within warehouse [4]. Those systems include functions for receiving, storage, order picking, packing, and shipping processes, inventory storage, order product mixing, cross docking and customer service, and material handling activities [5, 6].

Some of the benefits of WMS could be defined as reduce inventory and labour costs, increase storage capacity, customer service, and increase inventory accuracy. As transaction volume grows and business becomes more sophisticated, the need is created for appropriate and optimized integrated systems and information systems inside and outside the warehouses
[7]. The implementation of management systems is a very complicated and costly task, and their inappropriate use may lead the firm to bankruptcy. Consequently, evaluation of those management systems is a complex decision process, and detailed analysis supported with analytical methods is needed [8]. As Warehouses should be designed and automated to achieve high throughput rate and high productivity thereby firms should evaluate their warehouse systems with appropriate criteria and implement them properly to increase performance and efficiency. It is required to propose an astute warehouse management system with authentic-time control and automatic storage and retrieval systems (ASRS) in order to handle warehouse management quandaries such as advanced control systems [2,9]. The paper is designed to give warehouse executers and managers a useful framework for evaluating newer WMS with defining the best suitable WM operation criteria. Evaluation model improves returns from WMS implementations and helps optimize hardware and software investments and operational maturity. Therefore, the paper is to build up a decision support model for decision process while evaluating WMS alternatives for warehouse managers and executers.

WMS evaluation is a typical Multi Criteria Decision Making (MCDM) structure whose multi criteria should be considered in a decision making process, and a problem containing ambiguity, fuzziness, subjectivity, uncertainty, vagueness in evaluation process. Therefore, this paper focuses on MCDM techniques to assess the importance weights of evaluation criteria, and fuzzy set theory to get the importance ratings of the given alternatives in linguistic terms that parameterize with specialized triangular fuzzy numbers. 
The remainder of this paper is organized as follows. In the next part, we review warehouse management and warehouse management system literature. Then, the integrated fuzzy multi criteria decision support model is presented. Third part presents the real life application result to validate the proposed methodology. In the last part, a summary of our study, discussion of the limitations, and suggestions for future researches are presented.

\section{Literature review}

In recent years, there have been many researches on WMS considering different aspects but not on evaluation of a general management system in warehouses. The main objective behind a WMS is to monitor the warehouse operations such as movement and storage of materials within an operation and process the associated transactions [10]. Order picking processes [3, 10 $\div 13$, packaging processes [8, 14], bin-packing processes, demand and supply processes, allocating production [14], transportation [14], and inventory resources [4,14], storage allocation and assignment [1, 4, 14], stock management $[10,14,15]$, are some important criteria that are considered in the management phase.

Also, direct picking, replenishment, and put away could be counted as some of warehouse management activities and should be considered while evaluating WMSs [3]. Even though WMS can alter from one software vendor to another in an important way, the rudimental logic to prefer a coalescence of modules that item, location, quantity, unit of measure, and authoritatively mandate information to determine where to stock, where to cull, and in what sequence to perform these operations, the advanced management and processing within a system is also consequential [16]. In addition we can also include to warehouse operations the tracking systems and communication systems between work stations. WMSs are involute business applications that incline to require a plethora of custom settings, many system resources to run, and an abundance of perpetual data management to perpetuate to run.

Despite the long history of evaluation systems, there has not been much application on warehousing management system evaluation decisions. The following studies on warehouse management and systems can be mentioned: Berg and Zijm [1] discussed warehousing systems and presented a relegation of warehouse management quandaries and a hierarchical decision quandaries cognate with establishing warehousing systems, including justification, design, orchestrating and control issues. Korpela and Lehmusvaara [17] fixated on warehouse network evaluation and designed a customer oriented approach for evaluation and culled alternative warehouse systems utilizing analytic hierarchy process (AHP). Cakir and Canbolat [18] presented an inventory relegation system which is predicated on the fuzzy analytic hierarchy methodology and integrated fuzzy logic with authentic inventory data and as a result, they designed a decision making system with multi inventory relegation criteria. $\mathrm{Gu}$ et al. [4] summarized characteristics of various decision support models and solution algorithms related to inventory management.
Apak and Vayvay [19] discussed warehouse execution system evaluation criteria and proposed an evaluation methodology for warehouse executers applying fuzzy analytic methods that consider such evaluation criteria as Warehouse and Bin Configuration, Receiving and Quality Control, Business Process, Decision Support and Reporting, Security, Inventory Control, Inventory Optimization, Cycle Count, Packing and Shipping, Putaway and Picking. A decision making system is proposed by Min [20] to ameliorate warehouse productivity and fortify the warehousing link with supply chain network by applying a simulation model based on computer availed design, an analytic hierarchy process, and a forecasting technique.

However, evaluation of WMS is not mentioned in literature. The problem on evaluation WMS is the selection of software solutions among many products for the proper system [21, 22]. Hence, MCDM evaluation framework is adopted to manage this issue. MCDM has been widely applied to many practical decision making problems, which are containing conflicting criteria. Several studies have been applied to such managerial systems evaluation: Sen et al. [23] presented an integrated decision support system dealing with qualitative and quantities objectives for enterprise software selection. Buyukozkan and Ruan [24] presented a decision making model based on the fuzzy multi criteria decision making (F-MCDM) approach for quantifying the performance of software development projects. Hence to references MCDM method would be widely used in evaluating and selecting software systems.

\section{Methodology}

Model is based on fuzzy set theory within two integrated analytic methodologies. In MCDM, each criterion is required to be compared with other criteria in terms of their relative superiority for achieving the overall objective of the problem. Decision process is relatively arduous to provide exact numerical values for the comparison ratios. In order to cope with dubious judgments expressions were the ratios as fuzzy sets, which incorporate the vagueness of human mentally conceiving. In this section, we present fuzzy set theory. Then MCDM methodologies such as fuzzy analytic hierarchy process (F-AHP) and fuzzy analytic network process (F-ANP) will be explained in detail.

\subsection{Fuzzy Analytic Hierarchy Process}

The analytic hierarchy process is utilized to derive relative priorities on absolute scales from both discrete and perpetual paired comparisons in multilevel hierarchic structures. AHP is elongated into fuzzy AHP, bringing the triangular fuzzy number of the fuzzy set theory directly into the pair-sagacious comparison matrix of the AHP. In fuzzy AHP method, the decision maker can designate predilections in the form of natural language or numerical value about the paramountcy of each performance attribute.

Proposed methodology employs a Likert scale of fuzzy numbers and the $1 \div 9$ ratio scale has proven to an efficacious quantification scale for reflecting the 
qualitative information of a decision quandary and for enabling the unknown weights to be approximated fuzzy weights of decision elements. Apply $\alpha=1$ to obtain the positive matrix of decision maker $k, \widetilde{\boldsymbol{R}}_{m}^{k}=\left(\widetilde{r}_{i j}\right)_{m}^{k}$, and let

$\widetilde{r}_{i j}=\frac{1}{\widetilde{r}_{i j}}, \forall i, j=1,2, \ldots, n$.

The procedure of the F-AHP is described as follows:

Step 1: Identify the hierarchical structure of decision criteria. Then, each decision maker is asked to express relative importance of two decision elements in the same group with linguistic scale.

Step 2: Construct fuzzy matrices. The scores of pairwise comparison are transformed into linguistic variables, which are represented by positive triangular fuzzy numbers

$$
\widetilde{\boldsymbol{R}}^{k}=\left[\widetilde{r}_{i j}\right]^{k}
$$

where: $\widetilde{\boldsymbol{R}}^{k}$ - a positive reciprocal matrix of decision maker $k ; \quad \widetilde{r}_{i j}$ - relative importance between decision elements $i$ and $j$, and

$\widetilde{r}_{i j}=1, \forall i=j ;(1,1,1)$

Step 3: Calculate fuzzy weights. Based on the Lambda-Max method proposed by Csutora and Buckley [25] calculate the $\alpha=0$ to obtain the lower bound and upper bound positive matrices of decision maker $k$, $\widetilde{\boldsymbol{R}}_{l}^{k}=\left(\widetilde{r}_{i j}\right)_{l}^{k}$ and $\widetilde{\boldsymbol{R}}_{u}^{k}=\left(\widetilde{r}_{i j}\right)_{u}^{k}$. Based on the weight calculation procedure proposed in AHP, calculate weight matrix,

$$
\boldsymbol{W}_{m}^{k}=\left(w_{i}\right)_{m}^{k}, \boldsymbol{W}_{l}^{k}=\left(w_{i}\right)_{l}^{k} \text { and } \boldsymbol{W}_{u}^{k}=\left(w_{i}\right)_{u}^{k}, i=1,2, \ldots, n
$$

In order to minimize the fuzziness of the weight, two constants, $M_{l}^{k}$ and $M_{u}^{k}$, are chosen as follows:

$$
\begin{aligned}
& M_{l}^{k}=\min \left\{\frac{w_{i m}^{k}}{w_{i l}^{k}} \mid 1 \leq i \leq n\right\}, \\
& M_{u}^{k}=\min \left\{\frac{w_{i m}^{k}}{w_{i u}^{k}} \mid 1 \leq i \leq n\right\} .
\end{aligned}
$$

The upper bound and lower bound of the weight are defined as $w_{i l}^{{ }^{* k}}=M_{l}^{k} w_{i l}^{k}$ and $w_{i u}^{* k}=M_{u}^{k} w_{i u}^{k}$.

The upper bound and lower bound weight matrices are

$$
\begin{aligned}
& \boldsymbol{W}_{l}^{* k}=\left(w_{i}^{*}\right)_{l}^{k}, i=1,2, \ldots, n \\
& \boldsymbol{W}_{u}^{* k}=\left(w_{i}^{*}\right)_{u}^{k}, i=1,2, \ldots, n
\end{aligned}
$$

By combining $\boldsymbol{W}_{l}^{* k}, \boldsymbol{W}_{m}^{* k}$ and $\boldsymbol{W}_{u}^{* k}$ the fuzzy weight matrix for decision maker $k$ can be obtained and is defined as $\widetilde{W}_{i}^{k}=\left(w_{i l}^{* k}, w_{i m}^{* k}, w_{i u}^{* k}\right), i=1,2, \ldots, n$.

Step 4: Integrate the opinions of decision makers. Geometric average is applied to combine the fuzzy weights of decision makers:

$$
\tilde{W}=\left(\prod_{k=1}^{K} \tilde{W}_{i}^{k}\right)^{1 / K}, \forall k=1,2, \ldots, K
$$

where: $\tilde{W}_{i}$ - combined fuzzy weight of decision element $i$ of $K$ decision makers; $\tilde{W}_{i}^{k}$ - fuzzy weight of decision element $i$ of decision maker $k$; $K$ - number of decision makers.

In the process of hierarchy, a criterion is connected to a local weight and global weight. The local weight of a criterion is indicated to weight relative to other criteria. The local weights are converted to global weights by making the weight of their corresponding super-criterion be the geometric mean of these global weights. The geometric mean guarantees the consistency of the aggregate judgment matrix, regardless of the consistency measures of the individual judgment matrices for a sufficiently astronomically immense group size. The use of geometric mean in lieu of arithmetic mean to derive the priority vectors from fuzzy pair-sagacious comparison matrices is one of the best suited approaches.

\subsection{Fuzzy ANP}

Fuzzy ANP method is the methodology's second step. It is almost impossible to structure all decision quandaries hierarchically because of the interaction and dependence of higher calibre decision elements on lower elements [26, 27]. ANP, which is the extension of AHP, is developed by Saaty [26] as well to engender priorities for decisions without making postulations about unidirectional hierarchy relationship among decision levels. ANP provides a general framework to deal with decisions without making postulations about the independence of higher calibre elements from lower calibre elements and about the independence of the elements within a calibre. In fact the ANP utilizes a network without the desire to designate levels as in a hierarchy. Furthermore, ANP deals with dependence within a set of elements (inner dependence), and among different sets of elements (outer dependence) and, the looser network structure of ANP makes possible the representation of any decision quandary without concern for what comes first and what comes next as in a hierarchy. In order to evaluate the decision maker predilections, pair-sagacious comparison matrices are structured utilizing $\operatorname{TFN}(l, m, u)$. The $m \times n$ triangular fuzzy matrix can be given as follows:

$$
\widetilde{\boldsymbol{A}}=\left(\begin{array}{ccc}
\left(a_{11}^{l}, a_{11}^{m}, a_{11}^{u}\right) & \cdots & \left(a_{1 n}^{l}, a_{1 n}^{m}, a_{1 n}^{u}\right) \\
\vdots & \ddots & \vdots \\
\left(a_{m 1}^{l}, a_{m 1}^{m}, a_{m 1}^{u}\right) & \cdots & \left(a_{m n}^{l}, a_{m n}^{m}, a_{m n}^{u}\right)
\end{array}\right)
$$


The element $a_{m n}$ represents the comparison of the component $m$ (row element). If $\widetilde{\boldsymbol{A}}$ is a pair-wise comparison matrix in Eq. (8), it is assumed that it is reciprocal, and the reciprocal value. $\widetilde{\boldsymbol{A}}$ is also a triangular, fuzzy, pair-wise comparison matrix. For getting estimates for the fuzzy priorities, $\widetilde{w}_{i}$, where $\tilde{w}_{i}=\left(w_{k}^{l}, w_{k}^{m}, w_{k}^{u}\right)$, and $i=1,2, \ldots, n$, from the judgment matrix, $\tilde{A}$, which approximates the fuzzy ratios $a_{i j}$, so that $a_{i j} \cong \tilde{w}_{i} / \tilde{w}_{j}$. The geometric mean method is reasonable and effective, hence the triangular fuzzy weights representing the relative importance of the criteria.

$$
\widetilde{\boldsymbol{A}} \approx\left(\begin{array}{ccc}
(1,1,1) & \cdots & \left(a_{1 n}^{l}, a_{1 n}^{m}, a_{1 n}^{u}\right) \\
\vdots & \ddots & \vdots \\
\left(\frac{1}{a_{1 n}^{u}}, \frac{1}{a_{1 n}^{m}}, \frac{1}{a_{1 n}^{l}}\right) & \cdots & (1,1,1)
\end{array}\right) .
$$

For calculating triangular fuzzy weights can be given as follows.

$$
\tilde{w}_{k}=\left(w_{k}^{l}, w_{k}^{m}, w_{k}^{u}\right) \quad k=1,2,3, \ldots, n .
$$

where,

$$
w_{k}^{s}=\frac{\left(\prod_{j=1}^{n} a_{k j}^{s}\right)^{1 / n}}{\sum_{i=1}^{n}\left(\prod_{j=1}^{n} a_{i j}^{m}\right)}, s \in\{l, m, u\} .
$$

If there is no relationship between components, the corresponding matrix segment is a zero matrix. Then, the supermatrix is transformed into the weighted supermatrix, each of whose columns sum to one. The column stochastic feature of the weighted supermatrix sanctions converge to occur in the inhibition supermatrix. Finally, the weighted supermatrix is transformed into the inhibition supermatrix by raising it to powers [28]. The reason for multiplying the weighted supermatrix is to capture the transmission of influence along all possible paths of the supermatrix, which yields limit priorities capturing all of the direct and indirect influences of each element on every other element. When the supermatrix covers the whole network, the final priorities of elements are found in the corresponding columns in the inhibition supermatrix.

Similar methodology was preferred when the dependence is considered while in evaluation process; Lee et al. [29] proposed ANP approach to select appropriate acquisition mode for required technology.

\subsection{Fuzzy TOPSIS}

Technique for Order Preference by Similarity to Ideal Solution (TOPSIS) was developed by Yoon and Hwang in 1980. Fuzzy TOPSIS may be briefly described as follows [30]
1. Create Decision $(A)$ and Weight $(\boldsymbol{W})$ Matrices

2. Convert Criteria to the same Type

3. Create Fuzzy Decision $(\tilde{\boldsymbol{A}})$ and Weight $(\tilde{\boldsymbol{W}})$ Matrices: Criteria are divided into two groups as objective and subjective criteria [13]. "Error rate" term is defined to fuzzily the crisp terms into triangular fuzzy numbers (TFNs) in decision and weight matrices. Considering a TFN is formed by a triplet $\left\{\tilde{a}=\left(a_{1}, a_{2}, a_{3}\right)\right\}$, the most extreme values and the middle one can be computed according to Eq. (12).

$$
\begin{aligned}
& a_{1}=(\text { crisp data })-(\text { crisp data }) *(\text { error rate } / 100) \\
& a_{2}=(\text { crisp data }) \\
& a_{3}=(\text { crisp data })+(\text { crisp data }) *(\text { error rate } / 100)
\end{aligned}
$$

4. Create Normalized Fuzzy Decision Matrix $(\tilde{X})$ : The normalized fuzzy decision matrix is created as follows:

- For benefit criteria:

- Determine the highest value of $a_{3}$ 's in that column and equalize it to $x^{*}$.

- The normalized value of $\widetilde{a}=\left(\frac{a_{1}}{x^{*}}, \frac{a_{2}}{x^{*}}, \frac{a_{3}}{x^{*}}\right)$.

- For cost criteria:

- Determine the smallest value of $a_{1}$ 's in that column and equalize it to $x^{*}$.

- The normalized value of $\tilde{a}=\left(\frac{x^{*}}{a_{3}}, \frac{x^{*}}{a_{2}}, \frac{x^{*}}{a_{1}}\right)$.

5. Create Weighted Normalized Fuzzy Decision Matrix $(\tilde{\boldsymbol{Y}})$ : Each fuzzy performance value, $\left\{\tilde{a}_{i j}(i=1,2,3, \ldots, m)(j=1,2,3, \ldots, n)\right\}$, has to be multiplied with fuzzy weight, $\left\{\tilde{w}_{j}(j=1,2,3, \ldots, n)\right\}$, to obtain weighted normalized fuzzy decision matrix.

6. Determine Fuzzy Positive and Fuzzy Negative Ideal Solution Sets: Fuzzy positive ideal reference point, $A^{+}$and fuzzy negative ideal reference point, $A^{-}$are defined with Eqs. (13) and (14).

$$
\begin{aligned}
& A^{+}=\left(\widetilde{v}_{1}^{+}, \widetilde{v}_{2}^{+}, \ldots, \widetilde{v}_{n}^{+}\right) \\
& A^{-}=\left(\widetilde{v}_{1}^{-}, \widetilde{v}_{2}^{-}, \ldots, \widetilde{v}_{n}^{-}\right)
\end{aligned}
$$

where $\tilde{v}_{j}^{+}=(1,1,1)$ and $\tilde{v}_{j}^{-}=(0,0,0) ; j=1,2, \ldots, n$.

\section{Application}

The evaluation procedure of this study includes two steps. The first step is regarding our methodology, we asked to group cognate personnel to this evaluation process. This group is formed as the "decision makers" with fifty six members. The decision makers were industrial engineers, supply chain executors, and warehouse consultants. Those decision makers are capable to take decisions on WMSs due to their work experience and expertise on such systems. First two activities of the decision makers were to identify WMS 
alternatives and the decision criteria as defined in algorithm in Fig. 1.

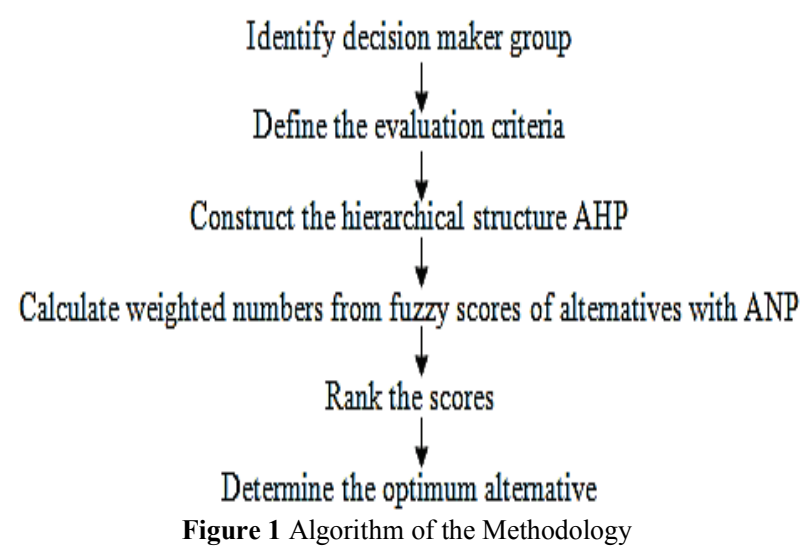

\subsection{Identification of criteria and alternatives}

It is possible to count many evaluation criteria in order to cull WMS among many, which subsist in the software market. Different evaluation criteria have been examined in the field of literature. In this study, the decision-making team has decided on fifteen main evaluation criteria based on their experience, studies in the literature and reports about such systems. Those criteria are widely used in such systems, which are decided to be used in evaluation process. Warehouse and Bin Configuration (WB): is a solution, which deals with automating inventory handling process. This feature is designed to utilize multiple bin configurations; Receiving and Quality Control (RQ): is an operator in inbound shipments by providing operations through the appropriate user interface; Business Process $(B P)$ : is an all related activities and tasks that produce a specific service or product for a particular customer. It visualizes a flowchart as a sequence of activities; Decision Support and Reporting $(D S)$ : is an inventory support system for current information assets and gives comparative operational figures between given period, projected revenue figures based on product assumptions; Security $(S C)$ : is to enhance security of the warehouse: the transport and logistics system for all inventory and the security requirements of the system; Inventory Control (IC): is related to product usage and costs, and maintains inventory at optimum levels; Inventory Optimization $(I O)$ : is to create an inventory optimization from multi suppliers through a multi-channel to customers; Cycle Time Analysis and Optimization (CT): is to analyse process time, during a product turn over in warehouse, and delay time, during which a unit of work is spent waiting to take the next operation; Cycle Count $(C C)$ : it is an inventory procedure where a subset of items are counted on any given period; Packing and Shipping (PS): is to make a link between an order and required packing materials and documents; Put away and Picking (PP): making a combination between product receipts and storage locations this should be fortified by a series of rules which are formed as a component of the system; Labour Allocation and Optimization (LA): is to make effort and optimize decisions based on long and shortterm economic work force at the enterprise level; Yard Management $(Y M)$ : is to analyse administration of a company's yard and dock doors also ensures that all of a business shipping and receiving requirements; Web Order Entry (WO): is to enable purchase orders to be entered into WMS through internet. System is used in the absence of host system, by third-party logistics providers that do not use a single host system. Return Material Authorization (RM): is to provide customer accommodation and give sales representatives the power to track return products from customers and to ameliorate customer gratification by providing a centralized application for ingression and resolution of material returns from customers.

While warehouse experts prefer those criteria, four different alternative WMSs are chosen due to market share in Turkey without giving any details about companies. According to given criteria and alternatives, application of the methodologies is mentioned in the next part.

\subsection{The weights of evaluation criteria, F-AHP}

After determining criteria, a questionnaire is designed to compare each criterion with AHP questionnaire format (nine-point scale and pairwise comparison). Fuzzy evaluation matrix established by the evaluation of proposed methods is given in Tab. 1 .

Table 1 Global fuzzy weights of modules from F-AHP

\begin{tabular}{|c|c|c|c|c|c|c|c|c|}
\hline & Modules & $u_{i j}$ & $l_{i j}$ & $m_{i j}$ & Modules & $u_{i j}$ & $l_{i j}$ & $m_{i j}$ \\
\hline & WB & 0,0052 & 0,0188 & 0,0437 & CC & 0,0036 & 0,0068 & 0,0102 \\
\hline & RQ & 0,0027 & 0,0101 & 0,0488 & PS & 0,0021 & 0,0048 & 0,0098 \\
\hline & BP & 0,0048 & 0,0091 & 0,0379 & PP & 0,0016 & 0,0022 & 0,0072 \\
\hline WMS & DS & 0,0066 & 0,0083 & 0,0141 & LA & 0,0029 & 0,0052 & 0,0113 \\
\hline & SC & 0,0026 & 0,0044 & 0,0104 & YM & 0,0045 & 0,0114 & 0,0417 \\
\hline & IC & 0,0067 & 0,0114 & 0,0554 & WO & 0,0081 & 0,0184 & 0,0457 \\
\hline & IO & 0,0081 & 0,0184 & 0,0457 & RM & 0,0084 & 0,0091 & 0,0379 \\
\hline & CT & 0,0055 & 0,0114 & 0,0417 & & & & \\
\hline
\end{tabular}

Decision makers were asked to form the decision matrix by comparing and contrasting the alternatives under each of the criteria discretely. Fuzzy evaluation matrix established by the development of alternative systems by linguistic variables in Tab. 2 and comparisons of each alternative is presented in Tab. 3. After determining linguistic judgments put into our framework model as a fuzzy numbers. 
Table 2 Linguistic variables for the preference rating of alternatives

\begin{tabular}{|l|c|}
\hline \multicolumn{1}{|c|}{ Linguistic variable } & Fuzzy scale \\
\hline Very Poor (VP) & $(0,0 ; 0,0 ; 0,2)$ \\
\hline Poor $(\mathrm{P})$ & $(0,0 ; 0,2 ; 0,4)$ \\
\hline Fair $(\mathrm{F})$ & $(0,3 ; 0,5 ; 0,7)$ \\
\hline Good $(\mathrm{G})$ & $(0,6 ; 0,8 ; 1,0)$ \\
\hline Very Good $(\mathrm{VG})$ & $(0,8 ; 1,0 ; 1,0)$ \\
\hline
\end{tabular}

The linguistic assessments represent combined opinions of decision makers. The importance of criteria is calculated by using Eq. (11).
The pairwise comparison matrices shown in Tab. 3 are constructed first by collecting individual judgments. As it is seen in Tab. 4, the expert team according to their capabilities of systems evaluates each module. For example, while warehouse and bin configuration (WB) module is getting "good $(\mathrm{G})$ " grade for alternative 1, alternative 2 gets "fair $(\mathrm{F})$ ". Those evaluations were done to consider each alternative system's property.

Table 3 Linguistic evaluation matrix for the alternatives

\begin{tabular}{|l|c|c|c|c|c|}
\hline \multicolumn{1}{|c|}{ Criteria } & \multicolumn{4}{c|}{ Alternatives } \\
\hline & Abbrev. & A1 & A2 & A3 & A4 \\
\hline Warehouse and Bin Configuration & WB & G & F & G & G \\
\hline Receiving and Quality Control & RQ & G & F & F & F \\
\hline Business Process & BP & F & F & P & VG \\
\hline Decision Support and Reporting & DS & P & P & P & P \\
\hline Security & SC & VG & F & G & G \\
\hline Inventory Control & IC & G & VG & VG & F \\
\hline Inventory Optimization & IO & G & F & F & VG \\
\hline Cycle Time Analysis and Optimization & CT & VG & G & F & P \\
\hline Cycle Count & CC & P & G & F & F \\
\hline Packing and Shipping & PS & VG & F & G & F \\
\hline Put-away and Picking & PP & G & VG & P & G \\
\hline Labour Allocation and Optimization & LA & F & G & P & F \\
\hline Yard Management & YM & VG & G & P & G \\
\hline Web Order Entry & WO & G & F & F & F \\
\hline Return Material Authorization & RM & VG & P & F & F \\
\hline
\end{tabular}

Table 4 Limited super matrix

\begin{tabular}{|c|c|c|c|c|c|c|c|c|c|c|c|}
\hline & Goal & WB & $\mathrm{RQ}$ & $\mathrm{BP}$ & $\ldots$ & $\mathrm{WO}$ & $\mathrm{RM}$ & A1 & $\mathrm{A} 2$ & A3 & A4 \\
\hline A1 & 0,1802 & 0,006 & 0,009 & 0,046 & & 0,039 & 0,074 & 1,000 & 0,000 & 0,000 & 0,000 \\
\hline $\mathrm{A} 2$ & 0,1771 & 0,046 & 0,016 & 0,013 & $\ldots$ & 0,012 & 0,026 & 0,000 & 1,000 & 0,000 & 0,000 \\
\hline A3 & 0,1564 & 0,010 & $\mathbf{0 , 0 3 7}$ & 0,009 & $\ldots$ & 0,023 & 0,066 & 0,000 & 0,000 & 1,000 & 0,000 \\
\hline A4 & 0,1632 & 0,013 & 0,014 & 0,010 & $\ldots$ & 0,009 & 0,023 & 0,000 & 0,000 & 0,000 & 1,000 \\
\hline WB & 0,000 & 0,000 & 0,000 & 0,000 & $\ldots$ & 0,000 & 0,000 & 0,000 & 0,000 & 0,000 & 0,000 \\
\hline RQ & 0,000 & 0,000 & 0,000 & 0,000 & $\ldots$ & 0,000 & 0,000 & 0,000 & 0,000 & 0,000 & 0,000 \\
\hline $\mathrm{BP}$ & 0,000 & 0,000 & 0,000 & 0,000 & $\ldots$ & 0,000 & 0,000 & 0,000 & 0,000 & 0,000 & 0,000 \\
\hline DS & 0,000 & 0,000 & 0,000 & 0,000 & $\ldots$ & 0,000 & 0,000 & 0,000 & 0,000 & 0,000 & 0,000 \\
\hline $\mathrm{SC}$ & 0,000 & 0,000 & 0,000 & 0,000 & $\ldots$ & 0,000 & 0,000 & 0,000 & 0,000 & 0,000 & 0,000 \\
\hline IC & 0,000 & 0,000 & 0,000 & 0,000 & $\ldots$ & 0,000 & 0,000 & 0,000 & 0,000 & 0,000 & 0,000 \\
\hline IO & 0,000 & 0,000 & 0,000 & 0,000 & $\ldots$ & 0,000 & 0,000 & 0,000 & 0,000 & 0,000 & 0,000 \\
\hline $\mathrm{CT}$ & 0,000 & 0,000 & 0,000 & 0,000 & $\ldots$ & 0,000 & 0,000 & 0,000 & 0,000 & 0,000 & 0,000 \\
\hline $\mathrm{CC}$ & 0,000 & 0,000 & 0,000 & 0,000 & $\ldots$ & 0,000 & 0,000 & 0,000 & 0,000 & 0,000 & 0,000 \\
\hline PS & 0,000 & 0,000 & 0,000 & 0,000 & $\ldots$ & 0,000 & 0,000 & 0,000 & 0,000 & 0,000 & 0,000 \\
\hline PP & 0,000 & 0,000 & 0,000 & 0,000 & $\ldots$ & 0,000 & 0,000 & 0,000 & 0,000 & 0,000 & 0,000 \\
\hline LA & 0,000 & 0,000 & 0,000 & 0,000 & $\ldots$ & 0,000 & 0,000 & 0,000 & 0,000 & 0,000 & 0,000 \\
\hline YM & 0,000 & 0,000 & 0,000 & 0,000 & $\ldots$ & 0,000 & 0,000 & 0,000 & 0,000 & 0,000 & 0,000 \\
\hline WO & 0,000 & 0,000 & 0,000 & 0,000 & $\ldots$ & 0,000 & 0,000 & 0,000 & 0,000 & 0,000 & 0,000 \\
\hline RM & 0,000 & 0,000 & 0,000 & 0,000 & $\ldots$ & 0,000 & 0,000 & 0,000 & 0,000 & 0,000 & 0,000 \\
\hline
\end{tabular}

\subsection{Fuzzy ANP and TOPSIS phases and results}

The network structure of the relationship model is defined. The relative importance of each criterion with respect to goal, selection of the most appropriate WMS is derived. The pair wise comparisons among criteria are carried out with respect to their criterion. The evaluation is completed when a relationship is defined between two criteria. After the decision makers did the comparisons, the corresponding weights of the alternatives were determined for each criterion.

Supermatrix is filled with the elicited weights in order to form unweighted supermatrix. Paired comparison values, which were completed with information of experts, have been transformed into a single value with taking their fuzzy values. Then, the values of fuzzy synthetic degrees are calculated for comparison values matrix's every line between alternatives. After this step, fuzzy artificial magnitude value is accumulated.

To choose best alternative which has the top value, we normalize each column in the limit super matrix in terms of alternatives. Unweighted supermatrix presents the pairwise comparisons in general form. Each criterion presents the relative weight to related criterion. For example, $W B$ criterion has a relative importance $(0,101)$ with $C T$ criterion. 
In order to determine the weights of both quantitative and qualitative factors, pairwise comparison matrix is composed with the intention of estimating the weights of factors which belong to zero-one factor group. Priority vector obtained by developing this matrix is assigned to be the weights of factors belonging to this group.

After engendering a weighted supermatrix, inhibition of the weighted supermatrix by raising it to a sufficiently arbitrarily immensely enormous power until it converges into a fixed supermatrix. The final priorities of the four alternative WMSs, appropriateness weighted indices.

As a result of F-ANP calculations, $A 1$ can be recommended to be acquired through alternatives due to its high priority 0,1802 gravity weight according to rows of each alternative. Proposed decision support system model determined an alternative within four alternatives.

Not surprisingly, the results gathered from the application of fuzzy TOPSIS methods illustrated the same results as F-ANP. $A 1$ is the most appropriate alternative while $A 2, A 3$ and $A 4$ are second and third respectively according to the predetermined criteria in the study. All others have the lowest grades having negligible ranking due to their close values.

\section{Conclusion}

Warehouse executers spend their valuable time to take critical decisions in each level of the operations. While evaluating a WMS, you are building up an incipient technology and an incipient look onto your system. With each amended technology there could be supplemental overhead and supplemental costs of current problems. Thus, WMS has to cope with potential operational problems, offer functionality to operators in warehouses to stay in competition.

Evaluation of such complex decision alternatives requires subjective systematic view with qualitative criteria. To solve this problem, we have evolved combined fuzzy MCDM approach. The method employs the application of the fuzzy MCDM approaches to problems. The decision makers should reduce complexity in WMS selection problem. In addition, structure of organization can help the executers identify the warehouse requirements. Need of appropriate managerial systems could be satisfied by using mathematical models with subjective judgments. Contribution of this study is the development of a working model of a fuzzy decision support system for evaluation of WMSs. As a further research, new criteria and other methodologies can be incorporated to the research.

\section{References}

[1] Van Der Berg, J. P.; Zijm, W. H. M. Models for warehouse management: Classification and examples. // International Journal of Production Economics. 59, 5(1999), pp. 19-528.

[2] Poon, T. C.; Choy, K. L.; Chow, H. K. H.; Lau, H. C. W.; Chan, F. T. S.; Ho, K. C. A RFID case-based logistics resource management system for managing order-picking operations in warehouses. // Expert Systems with Applications. 36, (2009), pp. 8277-8301. DOI: 10.1016/j.eswa.2008.10.011
[3] Shiau, J.-Y.; Lee, M.-C. A warehouse management system with sequential picking for multi-container deliveries. // Computers \& Industrial Engineering. 58, (2010), pp. 382392. DOI: $10.1016 /$ j.cie.2009.04.017

[4] Gu, J.; Goetschalckx, M.; McGinnis, L. F. Research on warehouse operation: A comprehensive review. // European Journal of Operational Research. 177, 1(2007), pp. 1-21. DOI: 10.1016/j.ejor.2006.02.025

[5] Rouwenhorst, B.; Reuter, B.; Stockrahm, V.; Van Houtum, G. J.; Mantel, R. J.; Zijm, W. H. M. Warehouse design and control: Framework and literature review. // European Journal of Operational Research. 122, (2000), pp. 515-533. DOI: 10.1016/S0377-2217(99)00020-X

[6] Coyle, J. J.; Bardi, E. J.; Langley, C. J. The management of business logistics, a supply chain perspective. St. Paul, M, Canada: West Publishing Co (2003), pp. 287-289.

[7] Gallmann, F.; Belvedere, V. Linking service level, inventory management and warehousing practices: A casebased managerial analysis. // Operations Management Research. 4, 1-2(2011), pp. 28-38.

[8] Min, H. The application of warehouse management system: an exploratory study. // International Journal of Logistics: Research and Applications. 9, 2(2006), pp. 111-126. DOI: 10.1080/13675560600661870

[9] Ballestin, F.; Perez, A.; Lino, P.; Quintannilla, S.; Valls, V. Static and dynamic policies with RFID for the scheduling of retrieval and storage warehouse operations. // Computers \& Industrial Engineering. 66, (2013), pp. 696-709. DOI: 10.1016/j.cie.2013.09.020

[10] Koster, R.; Le-Duc, T.; Roodbergen, K. J. Design and control of warehouse order picking: A literature review. // European Journal of Operational Research. 182, 2(2007), pp. 481-501. DOI: 10.1016/j.ejor.2006.07.009

[11] Ackerman, K. B. Practical Handbook of Warehousing (Fourth Ed.). Springer (1997). DOI: 10.1007/978-1-4615-60135

[12] Hsieh L. F.; Tsai, L. The optimum design of a warehouse system on order picking efficiency. // The International Journal of Advanced Manufacturing Technology. 28, 56(2006), pp. 626-637. DOI: 10.1007/s00170-004-2404-0

[13] Bortfeldt, A.; Mack, D. A heuristic for the threedimensional strip packing problem. // European Journal of Operational Research. 183, (2007), pp. 1267-1279. DOI: 10.1016/j.ejor.2005.07.031

[14] Turan Erman Erkan; Gulin Feryal Can. Selecting The Best Warehouse Data Collecting System By Using AHP And FAHP Methods. . // Tehnički vjesnik - Technical Gazette 21, 1(2014), pp. 87-93.

[15] Denis, D.; St-Vincent, M.; Imbeau, D.; Trudeau, R. Stock management influence on manual materials handling in two warehouse superstores. // International Journal of Industrial Ergonomics. 36, (2006), pp. 191-201. DOl: 10.1016/j.ergon.2005.11.002

[16] Lin, H. Y.; Hsu, P. Y.; Sheen, G. J. A fuzzy based decision making procedure for data warehouse system selection. // Expert Systems with Applications. 32, 3(2007), pp. 939953. DOI: 10.1016/j.eswa.2006.01.031

[17] Korpela, J.; Lehmusvaara, A. A customer oriented approach to warehouse network evaluation and design. // International Journal of Production Economics. 59, 13(1999), pp. 135-146. DOI: 10.1016/s0925-5273(98)00096-6

[18] Cakir, O.; Canbolat, M. S. A web-based decision support system for multi-criteria inventory classification using fuzzy AHP methodology. // Expert Systems with Applications. 35, 3(2008), pp. 1367-1378. DOI: 10.1016/j.eswa.2007.08.041

[19] Apak, S.; Vayvay, O. An Integrated decision support system for warehouse execution system evaluation under fuzzy environment. $/ / 7^{\text {th }}$ International Logistics \& Supply 
Chain Management Congress 5-6 Nov. 2009, Istanbul, Turkey (2009).

[20] Min, H. Application of decision support system to strategic warehousing decisions. // International Journal of Physical Distribution \& Logistics Management. 39, 4(2009), p. 270. DOI: 10.1108/09600030910962230

[21] Poon T. C.; Choy, K. L.; Chan, F. T. S.; Ho, G. T. S. Gunasekaran, A.; Lau, H. C. W.; Chow, H. K. H. A realtime warehouse operations planning system for small batch replenishment problems in production environment. // Expert Systems with Applications. 38, 7(2011), pp. 85248537. DOI: 10.1016/j.eswa.2011.01.053

[22] Gunasekaran, A.; Ngai, E. W. T.; Cheng, T. C. E. Developing an e-logistics system: a case study. // International Journal of Logistics: Research and Applications. 10, 4(2007), pp. 333-349. DOl: 10.1080/13675560701195307

[23] Sen, C.G.; Barcalı, H.; Sen, S.; Baslıgil, H. An integrated decision support system dealing with qualitative and quantative objectives for enterprise software selection. // Expert Systems with Applications. 36, (2009), pp. 52725283. DOI: 10.1016/j.eswa.2008.06.070

[24] Buyukozkan, G.; Ruan, D. Evaluation of software development projects using a fuzzy multi-criteria decision approach. // Mathematics and Computers in Simulation. 77, (2008), pp. 464-475. DOI: 10.1016/j.matcom.2007.11.015

[25] Csutora, R.; Buckley, J. J. Fuzzy hierarchical analysis: the Lambda-Max method. // Fuzzy Sets and Systems. 120, (2001), pp. 181-195. DOI: 10.1016/S0165-0114(99)00155-4

[26] Saaty, T. L.; Vargas, L. G. Decision Making with Analytic Hierarchy Process, Springer, New York (2006).

[26] Yanar, L.; Tozan, H. A fuzzy hybrid decision support system for interceptor baywatch boat propulsion system selection // Tehnički vjesnik - Technical Gazette. 19, 2 (2012), pp. 407-413

[28] Niemira M. P.; Saaty, T. L. An Analytic network process for financial-crisis forecasting. // International Journal of Forecasting. (2004), pp. 573-587. DOl: 10.1016/j.jiforecast.2003.09.013

[29] Lee, H.; Lee, S.; Park, Y. Selection of technology acquisition mode using the analytic network. // Mathematical and Computer Modeling. 49, 5-6(2008), pp. 1274-1282.

[30] Tolga, T.; Tozan, H.; Valíček, J.; Harničárová, M. A fuzzy based decision support model for non-traditional machining process selection. // Tehnički vjesnik - Technical Gazette. 20, 5(2013), pp. 787-793.

\section{Authors' addresses}

\section{Sinan Apak}

Maltepe University, Industrial Engineering Department, Maltepe, İstanbul, Turkey

E-mail: sinanapak@maltepe.edu.tr

Hakan Tozan (Corresponding author) Department of Industrial Engineering, Okan University, 34959 Akfirat-Tuzla, İstanbul, Turkey

E-mail: e.hakan.t@gmail.com; hakan.tozan@okan.edu.tr

\section{Özalp Vayvay}

Marmara University,

Industrial Engineering Department,

Kadıköy, İstanbul, Turkey

E-mail: ozalp@marmara.edu.tr 